\title{
THE IDENTITY COMPLEX: THE PORTRAYAL OF ARCHIVISTS IN FILM
}

\section{BY AMANDA OLIVER AND ANNE DANIEL}

\begin{abstract}
Archivists are depicted in various forms of media, and these representations influence how the world perceives the profession. This study, building on previous research, investigates how archivists are portrayed in film. The authors identified 43 films featuring archivists and conducted a content analysis of each film. The study reveals the lack of a clear image of archivists, who are presented as complex and sometimes ambiguous individuals. Many characters exhibit multifaceted personalities, and few fit the stereotypical qualities identified in previous research studies. This lack of a defined image may stem from a dearth of understanding of the archives profession among both the general public and individuals in the film industry. This poses a significant threat to the profession because it could lead to a lack of funding and an inability to attract donors, researchers, and future archivists. The archives profession must respond to these misconceptions and ambiguous images by engaging in proactive and consistent outreach. The search for a clear identity for archivists is ongoing. It offers an opportunity to generate discussion about the profession within the archival community and to make our complex professional identity accessible to the greater community.
\end{abstract}

\section{Introduction}

When Obi-Wan Kenobi speaks to the Jedi Archives' archivist in Stars Wars II: Attack of the Clones, he is informed that if a record is not in their archives it does not exist. ${ }^{1}$ The archivist is stern, terse, and absolute in her belief in the completeness of her records. This interaction conveys an unwelcoming vision of archives and archivists, and is one of many films to present a complex image of archivists.

Previous research focusing on the representation of archivists suggests that the archival profession has an image problem. Randall C. Jimerson stated that "The problem which archivists share with librarians and others is not just how to project a more positive image but how to reach agreement on exactly what image the profession wishes to send forth." If the archival community cannot agree on the image of an archivist, can we expect the media to provide an accurate representation of the profession?

This analysis of the presentation of archivists in film resulted in several key findings. Although some fictional archivists possess the stereotypical qualities identified in previous literature, the reel archivists examined in this study overwhelming possess 
unexpected qualities and behavioral attributes, such as power, rudeness, and unethical behavior, not found in past studies. Many characters exhibit multifaceted personalities, and few fit past stereotypes.

This article examines how archivists are represented in film and concludes that they are presented as complex, and possibly ambiguous, characters who do not fit into stereotypes identified in previous research studies. This examination of the complexity of film archivists also considers how these representations may pose a risk to the archival profession and provide an opportunity to discuss the profession's identity.

\section{Literature Review}

Authors surveying a wide range of media formats, including film, television, novels, and newspapers, have conducted a significant amount of research about librarians in pop culture; however, few have studied the representation of archivists in pop culture. This literature review focuses on the limited studies about archivists in pop culture and the perceived professional identity of archivists.

\section{Archivists in Pop Culture}

Three authors wrote about the portrayal of archivists in British, American, and Canadian newspapers. In 2010, Margaret Procter investigated the portrayal of archivists in the nineteenth-century British press. She found that "While archives are recognizable, physical objects, 'archivists' are defined only by the material with which they work; but exactly what this work is and what their association with 'archives' is remains obscure." The press described archivists in a variety of ways, such as managers, recordkeepers, historians, civil servants, teachers, and gatekeepers. Procter argued that the archival profession should interpret this ambiguity as flexibility.

Richard J. Cox studied the image of archives and archivists over eight months in New York Times coverage in 1993. Cox looked at the number of articles published that mentioned archivists and archival records. He concluded that archives were treated as "curiosities, generally associated with prominent individuals." ${ }^{4} \mathrm{He}$ identified the depiction of archives and archivists in the media including television, film, and literature as needing further research.

Barbara Craig examined the Canadian press from 1989 to 1994 and discovered 365 reports that featured archives. Her goal was to determine what information the general public receives about the work of archivists. Craig concluded that the "image of archivists is not negative but strikingly ambiguous." She also concluded that archivists need to be more involved in outreach to raise awareness of archives. Procter, Cox, and Craig all concluded that newspapers describe archives and archivists ambiguously. Does this ambiguity stem from the flexibility of archivists' roles, as Procter suggests, or does it stem from a lack of understanding about the archival profession? Is this ambiguity also present in the representation of archivists in film?

In 1979 and 1980, Peter Gillis investigated archives in espionage fiction. He uncovered three themes involving archives: records are used to piece together personal information about an individual; records are hidden to protect the greater community 
from a damaging truth; and, information is power. Gillis highlighted the importance of archives within this genre: "Indeed when information about the past is needed, spy fiction writers almost invariably have their agents or protagonists turn to some sort of archival institution. ${ }^{\prime 6}$ But what of archivists in other genres of fiction? Are they merely plot devices, or are they presented as more complex characters?

In 1997, Arlene B. Schmuland conducted a content analysis of 93 novels containing archives and archivists. She discussed in detail the physical and behavioral characteristics of archivists in fiction and common motifs used to describe archives. She argued that repetition reinforces stereotypes, and stereotypes of archivists are not changing. She concluded by providing examples of how the archival community can combat these stereotypes through outreach and increased visibility. ${ }^{7}$

In 1999, Schmuland expanded the study to 128 novels. She noted common themes of dust and death in the descriptions of archives. She made an interesting comment about the relationship between the value of archives and how they are portrayed in fiction: "If the author believes that archival records have informational value, the author is more likely to present archives in a positive light. Those authors who do not see the usefulness of archives are the authors most likely to use negative stereotypes and images in reference to the aspects of archival work that they do discuss." 8

Tania Aldred, Gordon Burr, and Eun Park investigated the portrayal of archivists in film in 2007. They hypothesized that reel archivists are portrayed as librarians and created a checklist for a content analysis of 19 films that include archivists. ${ }^{9}$ They discovered that reel archivists fall into many of the stereotypes presented in the literature, such as being reclusive and intelligent, but films do not depict them as librarians. Although this study was very thorough, the sample size of archivists in films was quite small.

In 2008, Karen Buckley investigated the portrayal of archivists in 35 novels and 34 films and television shows, though she did not have a systematic way for selecting novels or films. She discovered four themes: the protection of the record and the truth is synonymous; the archival experience is personal and reflective; archival records are lost or buried in the archives; and, "the archival record invariably centers around the search for self or truth."10

To summarize, many of the previous studies about archivists in pop culture discuss the general ambiguity about archival work and call for more outreach to address this ambiguity and promote the profession.

\section{Archivists and Identity}

While much research has been done on the topic of librarians and identity, less has been written about archivists and identity. Susan Chapdelaine chaired a task force of the New England Archivists organization that examined stereotypes of archivists. ${ }^{11}$ One of the reasons for establishing the task force was to combat the lack of understanding by stakeholders about archives because it could jeopardize the future of archives. This task force was formed in the 1980s, however, no final report was ever published.

Mark A. Greene examined how archivists can translate importance and value into power. The premise of his research was that archivists do not have visibility and power because they have a weak sense of identity. He stated that archivists must claim power by the "ways in which they wield power." 12 Part of the identity problem outlined by 
Greene is that archivists do not have a set of core values. Subscribing to a core set of values provides "a source of guidance and a source of power." ${ }^{13}$ His concluding statement asserts that "we can become more valuable; but only if we know our own values."14

Randall C. Jimerson looked at ways of redefining the image of archives and archivists. He purported that the archival profession is going through an identity crisis and that altering public stereotypes is not just an issue between archivists and their researchers but also between archivists and their colleagues. Jimerson also stated that "if we [archivists] have no clear image of ourselves, .. . the public will not understand our purpose either." 15 Jimerson outlined several ways to improve the identity of archivists including strategic planning, marketing orientation, and having an "outward looking attitude."

David B. Gracy II argued that the archival profession is facing many paradoxes and the time has come to address them. The most prevalent involves archivists and identity: "The most perplexing paradox must be the fact that the public values records but not keepers of records. The public can hardly have a brave vision of us, treated as it is to a steady diet of drivel about archivists and archives." ${ }^{\prime 16}$ He commented on stereotypes such as dusk and darkness being thoughtlessly perpetuated and proclaimed that the time is now to change these perceptions. ${ }^{17}$

Andrea Hinding discussed how the public thinks of archives in terms of stereotypes, such as "dust and dead accumulation" and her belief that if archives were better understood, their value would be more appreciated and this appreciation would translate into more resources. ${ }^{18}$ She suggested the profession should shift its focus outward to "acts of memory" and our contributions to the greater collective memory to find allies outside typical archives users and stakeholders. ${ }^{19}$

Jean-Pierre Wallot examined the role of the archivist in the information age and argued for change to stay relevant in the current, and coming, information climate. He suggested that the archival profession's identity will arise from forming new partnerships rather than defending archaic definitions of traditional archivists. ${ }^{20}$

Themes identified in this literature review include a stereotypical view of archivists, such as being quiet and isolated, as well as a general ambiguity about the profession in regard to job titles, tasks, and purpose. The notion of developing a core set of values and articulating those values to the public is frequently linked to archivists' identity. The most common theme in the literature is the need for change in the perception of archivists within and outside of the profession. This research study builds and expands on these themes.

\section{Methodology}

\section{Definition of Terms}

Archives and archivists come in many shapes and sizes. It may be difficult to determine if an institution is an archives or if an individual is an archivist if they are not clearly identified as such in a film or film credits. The following definitions of archives and archivists were used to identify and select films for analysis.

The Association of Canadian Archivists (ACA) defines archivists as “ . . work[ing] 
as part of government, corporations, museums, libraries, historical societies and many other groups to control and preserve the recorded memory of these organizations." 21 Tasks associated with archivists include appraisal, arrangement and description, preservation, reference, and outreach, among others. This study emphasized the tasks of archivists rather than their job titles in identifying reel archivists.

The Association of Canadian Archivists' defines archives thusly: "An archives works to acquire, preserve, and make available material collected under the terms of a particular mandate." 22 There are many types of archives, and they may contain records in a variety of formats.

\section{Identification of Films}

The first stage of this research process was to identify appropriate films. To be included, films needed to have characters that matched the ACA's definition of archivist as described above.

Films containing archivists were identified in the following ways: soliciting titles from colleagues via ARCAN-L Listserv and SAA Listserv; database searches including the Internet Movie Database and the American Film Institute database, and a literature review. The most significant challenge at this stage was identifying the archivists in the films. In some cases, archivists were presented as librarians, or other information professionals, and in other instances, the information professionals were not specifically identified in the film.

A total of 77 films were identified as potential candidates for this research study. Of these 77 films, 32 were eliminated because they did not include archivists (see Table 1). It was not possible to obtain copies of two films to view, and they were removed from our list. This left a total of 43 films that we viewed and analyzed. These films are listed in Appendix A. ${ }^{23}$

Table 1: Is an Archivist Present?

\begin{tabular}{|c|c|c|}
\hline Archivist Present & Number & Percentage \\
\hline Yes & 33 & $41 \%$ \\
\hline No & 34 & $43 \%$ \\
\hline Other information professional & 7 & $9 \%$ \\
\hline Unidentified professional & 6 & $7 \%$ \\
\hline Total & 80 & $100 \%$ \\
\hline
\end{tabular}

\section{Data Collection and Analysis}

Aldred, Burr, and Park created a checklist to evaluate films including archivists based upon stereotypes found in the literature. For the purposes of this study, the Aldred, Burr, and Park checklist was modified to include additional themes found in our literature review. To ensure a systematic collection of data, the checklist was completed while viewing each of the films. ${ }^{24}$ The checklist was organized into four 
categories: film information, character information, facility information, and comments. In the film information category, we supplied information about the film, such as title, director, year, and genre. In the character information category, we added details about the character performing archival tasks, such as name, job title, screen time, tasks performed, and behavioral attributes. In the facility information category, we filled in particulars on where the character was conducting archival tasks, such as type of facility, physical space, and security measures. In the comments section, we recorded any additional observations. Some data collected were not analyzed and will be used in future research.

We viewed the films multiple times to compare the portrayal of reel archivists to images discussed in the literature. We then recorded the data from the checklists in tables to determine the frequency of distribution of each variable and analyzed frequencies to ascertain trends. We grouped the results by theme, supporting them with observations made in the comments.

\section{Will the Reel Archivist Please Stand Up?}

Someone's name is an integral part of his or her character, as it is a means to identify and distinguish that person from others. The intended purpose of the character name field in the checklist was to give the archivist in the film an identifier; however, $33 \%$ of the archivists were not given a name during the film or in the film credits (see Table 2). Eleven percent of characters had "Archivist" as their character name. This implies that their professional tasks are their only identifiable characteristics. This may be because many of the archivists have little screen time or these characters are not seen as vital enough to the plot to warrant individual identifiers. Stripping the characters of their individuality has a dehumanizing effect, for they must rely on other attributes, such as job title or behavior, to establish their roles.

Table 2: Is the Archivist Named?

\begin{tabular}{|l|c|c|}
\hline \multicolumn{1}{|c|}{ Name Given } & Number & Percentage \\
\hline Yes & 26 & $56 \%$ \\
\hline No & 15 & $33 \%$ \\
\hline Job Title as Name & 5 & $11 \%$ \\
\hline Total & 46 & $100 \%$ \\
\hline
\end{tabular}

Job title, also noted on the film checklist, is, nonetheless, a very important factor in a person's identity. Of the films viewed, only $44 \%$ of characters conducting archival work had the words "archives" or "archivist" in their job titles; $30 \%$ had a variety of job titles such as "librarian," "file clerk," "records manager," "records keeper," or "attendant," and 26\% had no job title (see Table 3). 
Table 3: What Is the Archivist's Job Title?

\begin{tabular}{|l|c|c|}
\hline \multicolumn{1}{|c|}{ Job Title } & Number & Percentage \\
\hline Archivist & 20 & $44 \%$ \\
\hline Other Job Title & 14 & $30 \%$ \\
\hline Inidentified & 12 & $26 \%$ \\
\hline Total & 46 & $100 \%$ \\
\hline
\end{tabular}

Although a significant number of job titles had a direct link to archives, $56 \%$ were either unidentified or miscellaneous. This suggests a lack of clarity in regard to archivists. However, it is very ambiguous and also could indicate the flexibility and versatility of archivists. This corresponds to Procter's findings of a multitude of job titles describing archivists in her survey of British newspapers. ${ }^{25}$

Fifty-seven percent of film archivists were on screen for less than five minutes (see Table 4). Interactions with archivists are used to move the plot forward. The protagonist needs information, he or she visits the archives to obtain that information, and the plot continues on. Those characters on the screen for over 20 minutes were usually main characters and were not conducting archival work for the entirety of their screen time.

Table 4: How Long Is the Archivist On Screen?

\begin{tabular}{|l|c|c|}
\multicolumn{1}{|c}{ Screen Time Totals } & 26 & Percentage \\
\hline Less than 5 minutes & 7 & $57 \%$ \\
\hline $6-10$ minutes & 2 & $15 \%$ \\
\hline $11-15$ minutes & 1 & $4 \%$ \\
\hline $16-20$ minutes & 10 & $2 \%$ \\
\hline Over 20 minutes & 46 & $22 \%$ \\
\hline Total & & $100 \%$ \\
\hline
\end{tabular}

The lack of screen time and the fast-paced nature of archival research in film promotes the idea that archival research happens instantaneously. Most of the film archivists are on screen for less than five minutes and are able to help their researchers. This probably is due to the limited amount of time allotted for dramatic effect, but it presents the idea that archival work can be completed quickly, when in fact it often may take far more time for archivists or researchers to find what they are seeking. This may be promoting unrealistic expectations regarding how archival research is conducted.

In sum, character name, job title, and screen time all have a significant impact on the development of the image of archivists as presented in films. Many characters are not given names, or use their job titles as their names; many characters are conducting archival work but their job titles are not related to archives; and many characters are not on the screen for very long, let alone listed in the film's credits. This creates an ambiguous character who is difficult to relate to and understand. 


\section{Archivists with Attitude}

Although the archivists in the films seem to lack a clear identity, the characters still hold positions of power or they exude power. Gillis's 1990 study concluded that information as power is a prominent theme in spy fiction. ${ }^{26}$ Archivists are the keepers of information, and, therefore, one can conclude that archivists hold a substantial amount of power. This theme of power is prevalent in the films. The archivists exhibit power through specific behaviors including rudeness and unprofessional conduct, and by acting as a barrier between the researchers and information.

Table 5: How Does the Archivist Behave?

\begin{tabular}{|c|c|c|}
\hline Archivist Present & Number & Percentage \\
\hline Appreciates History & 10 & $10 \%$ \\
\hline Helpful & 10 & $10 \%$ \\
\hline Curious & 9 & $9 \%$ \\
\hline Disgruntled & 10 & $10 \%$ \\
\hline Ignored & 0 & 0 \\
\hline Impartial & 1 & 1 \\
\hline Introverted & 2 & 2 \\
\hline Isolated & 5 & 5 \\
\hline Knowledgeable & 25 & 24 \\
\hline Nervous & 3 & 3 \\
\hline Passive & 2 & 2 \\
\hline Quiet & 4 & 4 \\
\hline Territorial & 6 & 6 \\
\hline Other & 15 & 14 \\
\hline Total & 102 & $100 \%$ \\
\hline
\end{tabular}

Table 5 lists specific behaviors that we expected to find in the film archivists, as indicated by previous research; however, we did not. In hindsight, it is obvious that the specific traits in the table stem from a stereotypical view of archivists. Examples of these traits include introversion and passivity. Archivists in the films belie this stereotype. Many of the archivists in the films are assertive, forceful, and power-wielding characters. These unexpected traits reinforce the idea of a complex professional identity.

Elements of power and authority are inherent in the daily work of archivists. Buckley stated that ". . . not only does popular culture label the role of the archivist as one of 'guardian angel,' it places additional weight and emphasis on the role of the archival record being guarded." ${ }^{27}$ The task of guarding the past, present, and future is significant, and with it comes a degree of power. Archivists have the ability to grant access to records but also to impede access to records. Buckley summarized it very well 
when she stated that "they [archivists] are gatekeepers with the ultimate authority over access to the records sought by protagonists." ${ }^{28}$ In most cases, archival researchers must interact with archivists before they are able to access records. Archivists control access to records, and, as a result, they can either help or hinder the research process. Archivists also have the ability to change historical memory by preventing researcher access, changing the content of records, or destroying records. Without access to a complete body of records, the interpretation of history becomes skewed.

Perhaps archivists are not fully aware of the power they possess. The inability to recognize this power undermines the understanding of the profession not only by those on the outside but by the profession itself. The film archivists are depicted in a variety of ways and, while they exhibit elements of power through different behaviors, the underlying message of power is always present. In some cases, the manifestation of power is blatant, while in others it may be subtle.

\section{Liars and Vandals and Flirts, Oh My!}

The archivists in these films exhibit power in several ways, including unethical and unprofessional behaviors. Examples of such behaviors include flirting, bribery, theft, and tampering with records. In Scream 3, the archivist only helps the researcher after accepting the bribe of a \$2,000 ring. In Carolina Skeletons, the archivist steals a restricted document and gives it to the researcher. In Carolina Skeletons, Just Cause, and Erin Brockovich, the archivists flirt with the researchers. The Nasty Girl features an archivist who lies to a researcher to withhold access to the records. He uses a variety of fabricated and illegitimate excuses, including that the records are "too old and too young."

Bribery suggests power and that the person being bribed is in a position of authority and must be coerced into cooperating. In these films, the archivists have something that the researchers want-access to records or information. When the archivists do not provide access to or are uncooperative, the researchers resort to bribery. The power and control rests with the archivists; the researchers know this, and they use bribery as a tool to gain access to information.

Vandalism of and tampering with records is also directly related to power. In Watermelon Woman, the archivist redacts every Caucasian image in the archives because the archives is meant to capture African American history. The idea that archivists are free to change the records to reflect either their own views or institutional policies suggests that they have power and are at liberty to exercise that power whenever necessary. In some of the films, the archivists are directly responsible for theft of records. The records in Carolina Skeletons could not be accessed, so the archivist steals the relevant documents, removes them from the archives, and hands them to the researcher during a clandestine meeting in the forest. These examples demonstrate that film archivists can have complex relationships with their researchers.

Lying, vandalizing, and flirting (oh my!) are just a few character traits of archivists in the films. Portraying archivists in these ways contributes both positively and negatively to identity formation. It is positive in that it creates characters that capture attention with their interesting or exciting identities, which are distinctive, not easily forgotten, and help to squash the idea that archivists are introverts who manage dusty records. 
But these portrayals are also negative because they paint archivists as unprofessional. The contradictions create a conflicted image of the archival profession that results in an inconsistent identity.

\section{Please, Archivist, May I Have Some Records?}

The theme of archivists as gatekeepers repeats throughout the films. As keeper of the records, the archivist has the ability to prevent access and ultimately isolate the researcher from the records. This theme of isolation is presented in several ways, primarily through restrictions, but also through the lack of physical organization of the records and, in some cases, by the isolation of the archivist, the archives facility itself, and the researcher.

In some films, the archivist is presented as being isolated. Pearl, the archivist in Blade, is severely obese and does not wear any clothing. The archives is located in an isolated basement, and the entrance is hidden behind a freezer door. Her physical appearance isolates her from the researchers and the records as she is unable to move and must communicate with researchers via a computer. In the film The Time Machine, glass creates a physical barrier between the researcher and the archivist. The Avengers features an invisible archivist. Each of these examples illustrates the physical isolation of the film archivist.

This isolation presents the archivist as aloof, remote, and inaccessible. The researcher cannot form a connection with the archivist, and the lack of connection prevents him or her from developing a true and accurate understanding of the role of the archivist. Being an effective archivist means establishing relationships with both researchers and donors. Disconnection leads to a lack of understanding and this results in uncertainty, confusion, and, ultimately, an unclear identity for the archivist.

\section{Isolation of the Facility}

Sydney Levy argued that "Making archives a more common and accessible concept and doing more to open them to use and visiting, should diminish the various elements of dustiness and mustiness, sheer acquisitiveness, territoriality, and dead accumulation." ${ }^{29}$ Many of the films include elements of isolation of the archives facility. In Bartleby, there are no sidewalks to get to the archives building. In The Age of Stupid, the archives is remotely located eight hundred kilometers north of Norway. In The Time Machine, the archivist is an android in a glass enclosure. The Serpent's Egg depicts the archives as a difficult labyrinth to navigate. In Blade, the entrance to the archives is hidden behind a freezer. The archivist in You Are Here throws the keys to the archives down the sewer so nobody can enter. All of these examples picture archives as difficult to access.

Table 6 shows inconsistency in the depiction of archives facilities. Some facilities are pictured as dark and dusty; others are bright, clean, and organized. These widely divergent portraits make it difficult to establish a consistent identity for archives' facilities and archivists. While the depiction of archives facilities is varied, $36 \%$ of the films render archives as dark, underground, or basement facilities. Examples can 
be found in Blade, Red, Carolina Skeletons, and Carlton Browne of the FO. Being underground is associated with being lost or buried. The terms "digging" and "unearthing" are frequently used when referring to archival research. These examples and this terminology imply that archives facilities are hidden away and not easily accessible, suggesting isolation of the facility, of the records, and of the archivist.

Table 6: How Is the Archival Facility Depicted?

\begin{tabular}{|l|c|c|}
\multicolumn{1}{|c|}{ Physical Space } & Number & Percentage \\
\hline Bright & 3 & $4 \%$ \\
\hline Clean & 17 & $22 \%$ \\
\hline Dusty & 5 & $6 \%$ \\
\hline Dark & 9 & $11 \%$ \\
\hline Organized & 16 & $20 \%$ \\
\hline Unorganized & 9 & $11 \%$ \\
\hline Underground/Basement & 20 & $25 \%$ \\
\hline Total & 79 & $100 \%$ \\
\hline
\end{tabular}

In The Avengers, the archives is so dark that the staff and researchers have to use flashlights to see. This representation implies secrets and mystery and creates the impression that records are inaccessible. Darkness shrouds images. Darkness inhibits vision. This again is a metaphor for the shadowy archivist. Without a clear identity, he or she is also shrouded in mystery that keeps the researcher from understanding what archives are and what archivists do.

The idea that archives are difficult to access creates a negative impression for researchers, many of whom are already intimidated by archives' unfamiliarity. Portraying archives as inaccessible adds to the illusion that not everyone can use them. It mystifies the records and implies that archives are full of secrets.

\section{Isolation of the Records}

Thirty-two percent of the films make reference to restricted records or confidential information. We identified three categories of restrictions during this research: legitimate, arbitrary, and ambiguous.

Some of the films invoke legitimate restrictions, such as those required by privacy legislation. In the movie Deceived, the archivist advises that an individual's records can only be made public if the person is deceased. The archivist in Secret Nation tells the researcher that certain records are held in trust for 50 years. In The Nasty Girl, the researcher is told that the record donor's family must give permission for access.

Some of the films invent blatantly arbitrary restrictions enacted at the whim of the archivist or organization. For example, in Rollerball, the computer, against the 
archivist's wishes, will not answer a researcher's questions to protect the political organization in power. The archivist in The Girl with the Dragon Tattoo tells the researcher that she can have access to only one floor of records. In Blade, the archives is restricted to members only.

The restrictions in some of the films are ambiguous. There is no way to know if they are at all legitimate or are just in place because the archivist does not want to provide access. In Carolina Skeletons, the archivist says that the records are off limits to unauthorized personnel. In Call Northside 777, Watermelon Woman, and Silent Hill, the archivists all say that the records contain confidential information.

Two very similar examples of archivists actively hiding records figure in The Nasty Girl and In the Name of the Father. Throughout both films, the archivists repeatedly prevent the researcher from accessing the records. The archivist in The Nasty Girl uses various excuses: the researcher needs permission from the family, the records are too young, the records are too fragile, and the records are out on loan. The police archivist in In The Name of the Father provides access to only half of the police records as the other half incriminates the police force. In both instances, substitute archivists provide access to the records because they do not know that the original archivists are hiding the records. Both protagonists then steal the records from the archives because they know that once the permanent archivists return, access will be denied.

Restricting the archives can be problematic because, whether the restrictions are legitimate or not, the researcher may assume that the archivist is arbitrarily denying access to the records. In several of the films, researchers either imply or state outright that the archivists are trying to keep them from the records. Buckley suggested that this idea “. . . reflects a current cultural paranoia: records are destroyed or actively hidden by those in power in order to contain the spread of damaging secrets." 30 This paranoia is reflected in several of films, including In the Name of the Father, The Nasty Girl, Call Northside 777, The Girl with the Dragon Tattoo, and Star Wars II: Attack of the Clones.

Whether arbitrary or legitimate, the idea of restrictions in archives reinforces the sense of inaccessibility. Restrictions may perpetuate the misconception that archivists deliberately hide or withhold information from researchers without any valid reason. Restrictions also add mystery to the archives. Does the archives contain secrets? Is the archivist trying to keep the researcher from the records? If so, why?

The reverse could also be true. The cinematic portrayal of archival restrictions alerts viewers to the possibility that restrictions may exist, and that, as in the constraints required by privacy legislation, they may be legitimate. The reality is that not all records are open, and to portray them as such would be misleading. These films make evident the gray area around the understanding of privacy and access issues in archives and illustrate that film archivists have a complex relationship with their records.

\section{Isolation of the Researcher}

Many film archivists exert their power by being rude to their researchers. In Older than America, the archivist tells the researcher to "Knock yourself out";31 in Call 
Northside 777, the archivist tells the researcher that "if we kept that kind of stuff we would fill Soldier Field"; 32 and, in Chinatown, the archivist continues to work, without looking up from his task, while talking to the researcher. ${ }^{33}$ In The Girl with the Dragon Tattoo, the arrogant archivist tells the researcher that she cannot have access to the records and she will "just have to do without." ${ }^{34}$ In Star Wars II: Attack of the Clones, the haughty archivist advises the researcher that if a record isn't in the archives it doesn't exist. ${ }^{35}$

Rude behavior on the part of the archivists is a way of exercising power that ultimately could isolate researchers, leading them to feel uncomfortable in archives. Some researchers do not have a great deal of experience working with archival records, and this alone could be intimidating. Adding a rude and unhelpful archivist to the equation creates a further barrier.

Isolation of the archivist, of the facility, of the records, and of the researcher creates a disconnect between the researcher and the archivist. It makes both the archivist and the records inaccessible. This creates an aura of mystery, which in turn contributes to an unclear identity for the archivist. It is impossible for researchers to understand the archives if both the archivist and the facility are inaccessible.

What do the depictions of archivists with attitude and power mean for the identity of the archives profession? They are both beneficial and detrimental. They challenge the idea that archivists are meek and mild. They allow viewers to see archivists as more than dusty, dull characters toiling away in dark basements. But such depictions also contribute to the perception that archives are intimidating and that records are inaccessible. They identify archives as unwelcoming places where researchers receive no assistance. This creates a barrier between researchers and records. The ideal would be a more balanced portrayal of archivists who are, perhaps, more welcoming and connected to researchers. One could also argue that cinematic representation alone is sufficient and that archivists should be satisfied to have any presence in films at all.

\section{Archivist to the Rescue!}

These films also perpetuate the notion of the all-knowing archivist. When a researcher asks a very specific question, this archivist knows the answer. For example, in Scream 3, the archivist knows the stage name of an actress off the top of her head; in Shooting the Past, the archivist knows exactly where a photograph of a stakeholder's grandmother is located; in Red, the archivist knows the content of redacted records. Good archivists are extremely knowledgeable about their collections, but the concept of omniscience promotes unrealistic expectations about how archival research is conducted. These films use the all-knowing archivist as a plot device to supply information the protagonist needs and to move the story forward. This adds to the misconception about how archival research is conducted, providing a very narrow view of archival research in particular and archives in general. The idea of the all-knowing archivist oversimplifies the processes of reference, retrieval, and conducting archival research. 


\section{Rules? What Rules?}

Rules are an inherent part of archives, from the proper ways to use materials in reading rooms to the Rules for Archival Description. Archivists set guidelines to protect the records. Many of the film archives do not have rules. From the lack of rules for arrangement and description to the lack of reading room rules, in most cases the films do not make reference to any type of guidelines or standards of behavior. In some instances, the archivists themselves choose not to follow or enforce basic rules. In the film Watermelon Woman, the archivist presents a box of records to the researcher and then proceeds to dump the contents on the table. Several archivists offer food to researchers: the archivist in They Might Be Giants offers soup, and both the archivist and researcher in Shooting the Past eat an entire meal in the reading room. These depictions promote unrealistic expectations of how archival research is conducted and illustrate behaviors inappropriate while working in archives.

\section{Security Measures}

Many archives have security measures in place to protect their records, and our literature review turned up brief mentions of break-ins at fictional archives. We included questions regarding security measures on our checklist to investigate this further. Sixty-three percent of archives had some kind of security measures in place, such as security guards, registration desks, and, most frequently, closed stacks (see Table 7).

Table 7: What Are the Archives' Security Measures?

\begin{tabular}{|l|c|c|}
\hline \multicolumn{1}{|c|}{ Security Measures } & Number & Percentage \\
\hline Security Guard & 3 & $6 \%$ \\
\hline Registration & 6 & $13 \%$ \\
\hline Closed Stacks & 18 & $39 \%$ \\
\hline N/A & 17 & $36 \%$ \\
\hline Other & 3 & $6 \%$ \\
\hline Total & 47 & $100 \%$ \\
\hline
\end{tabular}

Adherence by the protagonist or researcher to the security measures in place was one of the data elements we collected (see Table 8 ). For $38 \%$ of the films, this question did not apply. Twenty-seven percent of protagonists adhered to the security measures of the archives, and 24\% did not. Judy in Misfiled, for example, asks her friend to call the archivist to distract her and then retrieves the information herself; Secret Nation, The Serpent's Egg, Blade, and Silent Hill show researchers breaking into archives after information; researchers in The Nasty Girl and In the Name of the Father steal records; and $8 \mathrm{~mm}$, Eric Brockovich, Scream 3, and National Treasure feature researchers using false credentials or lying to gain access to records. 
Table 8: Did Researcher Adhere to Security Measures?

\begin{tabular}{|l|c|c|}
\hline \multicolumn{1}{|c|}{ Adhere to Security Measures } & Number & Percentage \\
\hline Yes & 12 & $27 \%$ \\
\hline No & 11 & $24 \%$ \\
\hline N/A & 22 & $49 \%$ \\
\hline Total & 45 & $100 \%$ \\
\hline
\end{tabular}

This lack of respect for security measures implies the need to circumvent the archivist to gain access to records. It suggests that restrictions are arbitrary. This secrecy has a negative impact on the portrayal of archivists in film and is a risk to our perceived professional identity. In the applicable films, adherence to security measures and circumventing them is almost evenly split, which suggests a dichotomy in how archives and their security measures are perceived.

\section{Image? What Image?}

Our research suggests that there is no simple or easily defined representation of archivists in film. Film archivists display various behaviors that can each be interpreted in more than one way.

Archivists in film range from meek and mild to flirty and territorial. This variety of characteristics defies stereotyping and creates complex characters. Each element of behavior can be interpreted both positively and negatively. "Attitude" is a good example. The majority of archivists in the films exhibit certain attitudes in both positive and negative ways. Take assertiveness. Some of the film archivists are assertive yet friendly and protect their records using legitimate restrictions. Others are assertive and rude and prohibit researcher access to records. Does an archivist's assertive attitude contribute to his or her positive or negative portrayal? Does this serve the profession well, or does it hinder its growth and development? All of this contributes to a complex image of the archivist and the inability to define what an archives is and what an archivist does.

In some of the films, the archivists are willing to risk their professional integrity for personal gain by flirting and accepting bribes. Others of the archivists are depicted as being very helpful. Several films portray archivists as unaccommodating roadblocks between researchers and information. This presents an interesting dichotomy, and it leaves the viewer wondering about the true nature of archivists and archives. Ann Pederson stated in her 2003 article that "This risk is the fact archives and archivists are very poorly understood in the community, a situation that continues to hold us back professionally and puts the archival heritage itself in jeopardy." She went on, "With very few exceptions, the recordkeeping profession has failed to devise and communicate an accurate and positive image of itself and its discipline." ${ }^{36}$ The absence of a clear representation of archivists in films is evidence of poor communication between the profession and the larger community. ${ }^{37}$ 


\section{Conclusion}

This analysis of the characterization of archivists in films resulted in several key findings. Although some movie archivists possess the stereotypical qualities identified in the literature review, they overwhelmingly demonstrate unexpected qualities and behaviors, such as power, rudeness, and unethical behavior, not identified by past studies. For example, the literature makes many references to archivists being introverted, passive, mild mannered, and quiet. ${ }^{38}$ Gracy asked whether or not someone would want to go to "the stereotypical archivist . . . quiet and mousy." ${ }^{39}$ Our research identified film archivists who hold a substantial amount of power but are presented equivocally, which supports previous studies' finding that the media present archivists ambiguously. This undefined image may stem from a lack of understanding of the archives profession by both the general public and the film industry. This lack of understanding poses a significant threat to the profession because it could lead to limited funding and an inability to attract donors, researchers, and future archivists. Stakeholders will not invest in archives and donors will not donate records and/or money if they do not understand the role of archivists and the importance of the profession.

The archives profession must respond to these misconceptions and ambiguous images by engaging in proactive and consistent outreach to educate potential researchers, donors, and stakeholders about who archivists are, what they do, and why they are important. However, before this can be done, the archival community must decide what kind of image it wants to project. This is an opportunity for archivists to come together to define a clear identity for the profession and communicate this identity to our researchers and our donors, and to film creators and viewers. ${ }^{40}$

Is the representation of archivists as complex characters related to the variety of facilities where archivists work or the plethora of tasks for which archivists are responsible? Archivists work in a multitude of environments, including government, private, religious, and educational organizations. Archives may be within other institutions or standalone organizations. Archivists may be responsible for acquisition, appraisal, arrangement, description, preservation, conservation, disaster preparedness, reference, outreach, exhibits, budgets, and human resources, among other tasks. The archival profession is complex, and its representation in media should reflect this complexity; however, this complexity may be mistaken for ambiguity. Perhaps this indicates a need for transparency in regard to archival tasks and policies. Transparency may be vital to the demystification of the archival profession.

Several areas requiring further investigation and study emerged from this research. They include the link between confidentiality and security measures in fictional archives, the presentation of archives facilities in fictional settings, the quest for truth in fictional archives, and how the image of film archivists has changed over time. All of these areas are closely linked to the image of archivists and how archives and archivists are presented in pop culture.

The search for a clear identity for archivists is ongoing, and it is an opportunity to generate discussion about the profession within the archival community and to make our complex professional identity accessible to the wider world. 
ABOUT THE AUTHORS: Amanda Oliver is the lead archivist for the Archives Society of Alberta's Flood Advisory Programme. She holds a master of library and information science with a specialization in archives from McGill University and a bachelor of arts (honours) in English literature from Wilfrid Laurier University. She has held positions at a variety of archival institutions, including Library and Archives Canada and Western University Archives. Her research interests include the representation of archivists in pop culture and archival reference services.

Anne Daniel is an associate archivist at Western University. She holds an MLIS from Western University and a BASc from the University of Guelph. Her research interests include archivists in popular culture, outreach and social media, and the viability of finding aids vis a vis archival management systems. 


\section{Appendix A: Movies Included (Date in brackets is date of video/DVD release.)}

\begin{tabular}{|c|c|c|c|c|}
\hline Title & Year & Format & Director & Distributor \\
\hline $8 \mathrm{~mm}$ & 1999 (1999) & VHS & Joel Schumacher & $\begin{array}{l}\text { Columbia Tri-Star } \\
\text { Home Video }\end{array}$ \\
\hline The Age of Stupid & $2009(2010)$ & DVD & Franny Armstrong & Spanner Films \\
\hline Agnes of God & 1985 (2003) & DVD & Norman Jewison & $\begin{array}{l}\text { Columbia Tri-Star } \\
\text { Home Video }\end{array}$ \\
\hline American Splendor & $2003(2003)$ & DVD & $\begin{array}{l}\text { Shari Springer, } \\
\text { Berman/Robert Pulcini }\end{array}$ & Warner Home Video \\
\hline $\begin{array}{l}\text { Amityville Horror 2: } \\
\text { The Possession }\end{array}$ & $1982(1982)$ & DVD & Damiano Damiani & $\begin{array}{l}\text { MGM Home } \\
\text { Entertainment }\end{array}$ \\
\hline The Avengers & 1998 (1998) & DVD & Jeremiah Chechik & Warner Bros. \\
\hline Bartleby & 2001 (2001) & DVD & Jonathan Parker & Parker Film Company \\
\hline Blade & 1998 (1999) & DVD & Stephen Norrington & $\begin{array}{l}\text { Alliance Atlantis Home } \\
\text { Video }\end{array}$ \\
\hline Call Northside 777 & $1948(2005)$ & DVD & Henry Hathaway & $\begin{array}{l}\text { Twentieth-Century Fox } \\
\text { Home Entertainment }\end{array}$ \\
\hline $\begin{array}{l}\text { Carlton Browne of } \\
\text { the FO }\end{array}$ & 1959 (2003) & DVD & $\begin{array}{l}\text { Roy Boulting } \\
\text { Jeffrey Dell }\end{array}$ & $\begin{array}{l}\text { Anchor Bay } \\
\text { Entertainment Inc. }\end{array}$ \\
\hline Carolina Skeletons & 1991 (1991 & DVD & John Erman & $\begin{array}{l}\text { The Kushner-Locke } \\
\text { Company }\end{array}$ \\
\hline Chinatown & $1974(1999)$ & DVD & Roman Polanski & Paramount Home Video \\
\hline Citizen Kane & $1941(2001)$ & DVD & Orson Welles & Warner Home Video \\
\hline Cloud Atlas & 2012 (2013) & DVD & $\begin{array}{l}\text { Tom Tykwer, } \\
\text { Andy Wachowski, } \\
\text { Lana Wachowski }\end{array}$ & Warner Home Video \\
\hline $\begin{array}{l}\text { The Company } \\
\text { You Keep }\end{array}$ & $2012(2013)$ & DVD & Robert Redford & $\begin{array}{l}\text { Sony Pictures Home } \\
\text { Entertainment }\end{array}$ \\
\hline Deceived & 1991 (2012) & DVD & Damian Harris & Mill Creek Entertainment \\
\hline Enough Said & $2013(2013)$ & DVD & Nicole Holofcener & Twentieth-Century Fox \\
\hline Erin Brockovich & $2013(2013)$ & DVD & Steven Soderbergh & $\begin{array}{l}\text { Universal Studios Home } \\
\text { Video }\end{array}$ \\
\hline $\begin{array}{l}\text { The Girl with the } \\
\text { Dragon Tattoo }\end{array}$ & 2011 (2012) & DVD & David Fincher & $\begin{array}{l}\text { Sony Pictures } \\
\text { Home Entertainment }\end{array}$ \\
\hline $\begin{array}{l}\text { In the Name of the } \\
\text { Father }\end{array}$ & $1993(1998)$ & DVD & Jim Sheridan & $\begin{array}{l}\text { Universal Studios } \\
\text { Home Video }\end{array}$ \\
\hline Just Cause & 1995 (1999) & DVD & Arne Glimcher & Warner Home Video \\
\hline
\end{tabular}




\begin{tabular}{|c|c|c|c|c|}
\hline Title & Year & Format & Director & Distributor \\
\hline The Lives of Others & $2006(2006)$ & DVD & $\begin{array}{l}\text { Florian Henckel } \\
\text { von Donnersmarck }\end{array}$ & $\begin{array}{l}\text { Sony Pictures Home } \\
\text { Entertainment }\end{array}$ \\
\hline Mama & $2013(2013)$ & DVD & Andres Muschietti & $\begin{array}{l}\text { Universal Studios Home } \\
\text { Entertainment }\end{array}$ \\
\hline $\begin{array}{l}\text { The Mask of the } \\
\text { Dimitrios }\end{array}$ & $1944(1996)$ & DVD & Jean Negulesco & MGM/UA Home Video \\
\hline $\begin{array}{l}\text { Misfiled: An Archival } \\
\text { Murder Mystery }\end{array}$ & $2006(2006)$ & DVD & Felan Parker & $\begin{array}{l}\text { Ottawa Diocesan } \\
\text { Archives }\end{array}$ \\
\hline The Nasty Girl & 1990 (1991) & VHS & Michael Verhoeven & $\begin{array}{l}\text { Cineplex-Odeon Home } \\
\text { Video }\end{array}$ \\
\hline National Treasure & $2004(2005)$ & DVD & Jon Turteltaub & Walt Disney Home Video \\
\hline Older than America & $2008(2010)$ & DVD & Georgina Lightning & MPI Home Video \\
\hline Possession & 2002 (2003) & DVD & Neil LaBute & $\begin{array}{l}\text { Alliance Atlantis } \\
\text { Home Video }\end{array}$ \\
\hline Red & $2010(2011)$ & DVD & Robert Schwentke & Summit Home Video \\
\hline Rollerball & $1975(2000)$ & DVD & Norman Jewison & $\begin{array}{l}\text { MGM/UA Home } \\
\text { Entertainment }\end{array}$ \\
\hline Scream 3 & 2000 (2011) & DVD & Wes Craven & $\begin{array}{l}\text { Lionsgate Home } \\
\text { Entertainment }\end{array}$ \\
\hline Secret Nation & 1992 (1992) & DVD & Michael Jones & Black Spot \\
\hline The Serpent's Egg & 1977 (2004) & VHS & Ingmar Bergman & $\begin{array}{l}\text { MGM Home } \\
\text { Entertainment }\end{array}$ \\
\hline Shooting the Past & 1999 (1999) & DVD & Stephen Poliakoff & $\begin{array}{l}\text { British Broadcasting } \\
\text { Corporation }\end{array}$ \\
\hline Silent Hill & $2006(2006)$ & DVD & Christophe Gans & $\begin{array}{l}\text { Sony Pictures Home } \\
\text { Entertainment }\end{array}$ \\
\hline $\begin{array}{l}\text { Star Wars II: Attack of } \\
\text { the Clones }\end{array}$ & $2002(2005)$ & DVD & George Lucas & $\begin{array}{l}\text { Twentieth-Century Fox } \\
\text { Home Entertainment }\end{array}$ \\
\hline They Might Be Giants & $1971(2000)$ & DVD & Anthony Harvey & $\begin{array}{l}\text { Anchor Bay } \\
\text { Entertainment }\end{array}$ \\
\hline The Time Machine & $2002(2002)$ & DVD & Simon Wells & Warner Bros. \\
\hline The Treasure & 1990 (1992) & VHS & Robert Cording & Malofilm Home Video \\
\hline Vampires & $1998(1999)$ & DVD & John Carpenter & $\begin{array}{l}\text { Sony Pictures } \\
\text { Entertainment }\end{array}$ \\
\hline Watermelon Woman & 1996 (1997) & DVD & Cheryl Dunye & First Run Features \\
\hline You Are Here & 2010 (2011) & DVD & Daniel Cockburn & $\begin{array}{l}\text { Cross Country } \\
\text { Entertainment }\end{array}$ \\
\hline
\end{tabular}




\section{Appendix B: Film Checklist ${ }^{41}$}

Film ID:

Film Title:

Director:

Year Released:

Film Genre:

\ Action

- Comedy

๑ Drama

\ Horror

○ Other:

\section{Character Information}

Is there an archivist in the film:

○ Yes

ป No

ป Unidentified

$\checkmark$ Other information profession

Character's name:

Job title:

Screen time:

ป Less than 5 minutes

ป 6-10 minutes

ป 11-15 minutes

ป 16-20 minutes

\ Over 20 minutes

Tasks performed: (check all applicable tasks)

\ Accessions

acquisitions

$\checkmark$ Arrangement/Description

$\checkmark$ Outreach

$\square$ Reference

$\checkmark$ Research

$\checkmark$ Retrieval

$\checkmark$ Filing

๑ Other:

\section{Gender:}

a Male

๑ Female

๑ Other: 
Age:

ป Under 34

口 35-49

口 Over 50

Glasses:

a Yes

ป No

Dress:

\ Business attire

- Casual

○ Other:

Behavioral attributes:

appreciates history

a Curious

$\checkmark$ Disgruntled

- Helpful

Ignored

- Impartial

- Introverted

$\checkmark$ Isolated

- Knowledgeable

- Nervous

a Passive

$\square$ Quiet

Territorial

口 Other:

Facility information:

Name of facility (if provided):

Type of facility:

a Academic

a Business

$\square$ Government

a Religious

口 Other: 
Type of workspace (file room, etc.):

Physical space:

Bright

$\square$ Clean

Dusty

๑ Dark

- Organized

- Unorganized

Underground/basement

○ Other:

\section{Security measures:}

- Security guard

- Registration

- Closed stacks

D N/A

Does the protagonist adhere to the security measures or rules of the facility?

\Yes

- No

N/A

If no, please explain:

Was the character central to the researcher finding their information?

$\square$ Yes

- No

D N/A

\section{NOTES}

1. Star Wars II: Attack of the Clones, directed by George Lucas (2002; USA: Twentieth-Century Fox Home Entertainment, 2005), DVD.

2. Randall C. Jimerson, "Redefining Archival Identity: Meeting User Needs in the Information Society," The American Archivist 42, no. 3 (1989): 336.

3. Margaret Procter, "What's an 'Archivist'? Some Nineteenth-Century Perspectives," Journal of the Society of Archivists 31, no. 1 (2010): 15.

4. Richard J. Cox, "International Perspectives on the Image of Archivists and Archives: Coverage by the New York Times, 1992-1993," International Information and Library Review 25 (1993): 221.

5. Barbara Craig, "'What the Papers Say': Archives in the English-Language Canadian Public Press, 1989-1994," Archivaria 40 (1995): 116.

6. Peter Gillis, "Of Plots, Secrets, Burrowers and Moles: Archives in Espionage Fiction," Archivaria 9 (1979-1980): 5.

7. Arlene B. Schmuland, "The Image of Archives and Archivists: Fictional Perspectives" (master's thesis, Western Washington University, 1997).

8. Arlene B. Schmuland, "The Archival Image in Fiction: An Analysis and Annotated Bibliography," The American Archivist 62, no. 1 (1999): 53.

9. Tania Aldred, Gordon Burr, and Eun Park, "Crossing a Librarian with a Historian: The Image of Reel Archivists," Archivaria 66 (2008): 58. 
10. Karen Buckley, "The Truth Is in the Red Files': An Overview of Archives in Popular Culture," Archivaria 66 (2008): 98.

11. Susan Chapdelaine, “Archival Image Assessed,” New England Archivists Newsletter 11 (April 1984): 5 .

12. Mark A. Greene, "The Power of Archives: Archivists' Values and Value in the Postmodern Age," The American Archivist 72, no. 1 (2009): 20.

13. Ibid., 39 .

14. Ibid., 41.

15. Jimerson, "Redefining Archival Identity: Meeting User Needs in the Information Society," 336.

16. David B. Gracy II, "Is There a Future in the Use of Archives?," Archivaria 24 (1987): 15.

17. Ibid.

18. Andrea Hinding, "Archivists and Other Termites," The American Archivist 56 (1993): 56.

19. Ibid., 57.

20. Jean-Pierre Wallot, "Limited Identities for a Common Identity: Archivists in the Twenty-First Century," Archivaria 41 (1996): 20.

21. Association of Canadian Archivists, "What Is an Archivist?," accessed September 2, 2013, http:// archivists.ca/sites/default/files/Attachments/Outreach_attachments/What-an-Archivist.PDF.

22. Association of Canadian Archivists, "What Is an Archives?," accessed September 2, 2013, http:// archivists.ca/sites/default/files/Attachments/Outreach_attachments/Whats-an-Archives.PDF.

23. Some of the films included do not have a character with the role of archivist but rather only show a facility so we collected the data for future research (about the facility) but did not include them in this paper.

24. See Appendix B.

25. Procter, "What's an 'Archivist'? Some Nineteenth-Century Perspectives," 15.

26. Gillis, "Of Plots, Secrets, Burrowers and Moles," 3.

27. Buckley, "The Truth Is in the Red Files," 103.

28. Ibid.

29. Sidney J. Levy and Albert G. Robles, The Image of Archivists: Resource Allocators' Perceptions (Chicago: Society of American Archivists, 1984), v.

30. Buckley, "The Truth Is in the Red Files," 105.

31. Older than America, directed by Georgina Lightning (2008; USA: MPI Home Video, 2010), DVD.

32. Call Northside 777, directed by Henry Hathaway (1948; USA: Twentieth-Century Fox Home Entertainment, 2005), DVD.

33. Chinatown, directed by Roman Polanski (1974; USA: Paramount Home Video, 1999), DVD.

34. The Girl with the Dragon Tattoo, directed by David Fincher (2011; USA: Sony Pictures Home Entertainment, 2012), DVD.

35. Star Wars II.

36. Ann Pederson, "Understanding Ourselves and Others: Australian Archivists and Temperament," Archival Science 3 (2003): 224.

37. All of this being said, several films convey realistic portrayals of archivists. These films include Secret Nation (1992), The Mask of the Dimitros (1944), Enough Said (2013), and The Lives of Others (2006). These films present archivist characters who are believable, professional, and realistic.

38. Aldred, Burr, and Park, "Crossing a Librarian with a Historian," 67.

39. Gracy, "Is There a Future," 6.

40. The Association of Canadian Archivists and the Society of American Archivists have engaged in several advocacy initiatives to promote the profession, including statements of values, codes of ethics, and Archives Month.

41. This film checklist was modeled after the checklist used in Aldred, Burr, and Park's 2007 study. 